\title{
Analisis Perbandingan Resiko dan Kinerja Biaya Pada Proyek Konstruksi antara Pemerintah dan Swasta
}

\author{
SATRIA TRI NANDA \\ Jurusan Akuntansi Universitas Lancang Kuning \\ Jln. Yos Sudarso KM 8 Rumbai, Pekanbaru, Telp (0761) 52581 Fax (0761) 52581. \\ Email; satriatrinanda@yahoo.com
}

\begin{abstract}
This research was conducted to investigate the project cost effectivity and the level of construction contract risk in construction contract risks toward cost performance in either state-owned or private-owned projects. The population included the key person-level employees of Operation Division I PT. PP (Persero) Tbk. The sample consisted of 100 informants who were selected by using cluster sampling method. The variables are construction contract risks, consists of: work scope, project execution time, lumpsum price, payment method, additional/reduction work, and contract ending as independent variable, while cost performance used as dependent variable. The data were analyzed with compare means analysis using SPSS 17 for windows. The results show that the project cost control in state-owned project is already effective, while in private-owned project is still not effective. In the perspective of construction contract risk, either in state-owned or private-owned projects, both are facing the same high risk of discrepancies.
\end{abstract}

Keywords: Construction Contract Risk, Risk Management, Effectivity, Project Cost

Industri jasa konstruksi merupakan salah satu sektor yang sangat berperan dalam menentukan langkah kegiatan ekonomi. Sektor konstruksi juga menjadi penggerak sektor-sektor lainnya, maka perlu sekiranya mendapatkan perhatian yang baik dari seluruh stake holders. Pada kenyataannya, seringkali ditemukan pengelolaan proyek masih belum terpenuhi pencapaian kinerja yang optimal dan mengalami ketrlambatan pengerjaan. Hal ini dapat dilihat pada beberapa kurun waktu terakhir banyak proyek pemerintah yang terbengkalai pekerjaannya. Keterlambatan pelaksanaan dan penyelesaian proyek membuat target waktu menjadi diluar perencanaan. Hasil akhir yang kurang memenuhi standar mutu yang disepakati beresiko membuat pekerjaan ulang (rework) yang berakibat proyek tidak selesai pada waktunya. Masalah waktu dan mutu pada akhirnya bermuara kepada pembengkakan biaya pelaksanaan final sebuah proyek.

Permasalahan berupa pembengkakan biaya pada satu proyek konstruksi cukup sering terjadi yang disebabkan oleh berbagai aspek, seperti cuaca, asuransi, dan material (Rianto, 2009). Perubahan-perubahan harga material dalam sebuah kontrak lump sum (harga borongan) tentu membawa dampak tambahan biaya bagi kontraktor apabila dalam perencanaannya tidak mengantisipasi tingkat inflasi harga-harga material yang dibutuhkan. Faktor efektivitas sumber daya manusia juga memiliki peranan penting yang bisa mempengaruhi kinerja biaya proyek, seperti rendahnya tingkat pemahaman personil terhadap jadwal pelaksanaan proyek (Novrianti, 2008). Belum lagi skill pelaksana yang kurang bisa mendukung pelaksanaan proyek secara optimal juga bisa menyebabkan perencanaan biaya meleset dari target (Fassa, 2011). Dari sisi teknis pun tak kurang dampak buruknya apabila tidak dipahami dan dikelola secara profesional. Misalnya, kekeliruan dalam perencanaan gambar/desain, kualitas penawaran kontraktor kepada pengguna jasa, dan metode pengendalian biaya menjadi faktorfaktor lain yang signifikan di dalam pelaksanaan proyek konstruksi (Yansen, 2010). Dari hasil wawancara penulis dengan beberapan key person di PT. PP (Persero) Tbk diperoleh informasi bahwa kondisi kontrak juga sangat menentukan efektivitas 
pelaksanaan biaya proyek. Kondisi kontrak yang lemah akan berdampak negatif pada kinerja biaya proyek konstuksi.

Adanya resiko-resiko yang kemudian dibiayakan di dalam sebuah kontrak konstruksi tentu saja membawa pengaruh terhadap penetapan harga penawaran kontraktor (Sofyan, 2010). Hal ini wajar mengingat di dalam kontrak terdapat estimasi biaya yang dirancang seakurat mungkin untuk mengurangi dampak resiko yang bisa terjadi. Shelton (2002) menyatakan bahwa biaya merupakan salah satu aspek penting, bahkan mungkin yang terpenting dalam siklus kegiatan usaha dan industri konstruksi. Kontraktor yang tidak mempunyai pemahaman tentang komponen biaya, termasuk di dalamnya biaya tidak langsung, akan meningkatkan resiko dan eksposur mereka terhadap kegagalan yang tidak perlu.

Pada umumnya, segala bentuk antisipasi resiko dimanifestasikan dalam bentuk penyusunan sebuah kontrak kerja yang melibatkan pihak-pihak berkepentingan dalam pelaksanaan proyek tersebut. Akantetapi pada kenyataannya, masih banyak pelaksanaan proyek tidak sesuai dengan isi/materi yang ditetapkan di dalam kontrak. Seringkali ditemui penyimpangan dalam pelaksanaannya seperti waktu, biaya dan kualitas proyek. Hal ini dialami juga oleh PT. Pembangunan Perumahan (Persero)Tbk. Dari beberapa proyek yang dilakukan, baik pada proyek pemerintah maupun swasta, sering ditemui sejumlah penyimpangan antara isi kontrak dengan pelaksanaannya yang diakibatkan oleh sejumlah faktor. Permasalahan kontrak yang sering terjadi adalah: ambiguitas isi kontrak yang kerap menimbulkan perbedaan penafsiran antara pemilik dengan pelaksana proyek; penggunaan sub kontraktor yang dinominasikan oleh owner tidak memiliki profesionalitas sebagaimana yang diharapkan, penundaan pembayaran dengan berbagai alasan, dan lain sebagainya. Dari beberapa permasalahan diatas, penelitian ini mencoba menganalisis perbandingan resiko dan kinerja biaya pada proyek-proyek di laksanakan oleh PT. PP (Persero) Tbk Divisi Operasi I baik pada proyek-proyek pemerintah maupun swasta.

Manajemen proyek kini merupakan keharusan, bukan lagi sekedar pilihan. Ini berarti bahwa pekerjaan-pekerjaan tertentu akan lebih efisien dan efektif jika dikelola dalam kerangka proyek dan bukan diperlakukan sebagai pekerjaan biasa. Dengan demikian maka diperlukan penerapan manajemen proyek secara benar. Maka memahami manajemen proyek secara benar sangat penting dalam rangka melaksanakan proyek.

Malik (2010) mendefinisikan proyek sebagai sekumpulan kegiatan terorganisasi yang mengubah sejumlah sumber daya menjadi satu atau lebih produk barang/jasa bernilai terukur dalam sistem satu siklus, dengan batasan waktu, biaya dan kualitas yang ditetapkan melalui perjanjian. Pengertian ini mengandung makna bahwa tujuan proyek adalah menghasilkan produk akhir (output) berupa barang dan jasa yang diperoleh dari hasil elaborasi berbagai sumber daya (input). Proses transformasi ini dilakukan dalam jangka waktu tertentu (terbatas) dengan biaya dan kualitas yang diatur dalam sebuah perjanjian para pihak terkait.

Menurut Santosa (2009), manajemen proyek adalah aplikasi pengetahuan (knowledges), keterampilan (skills), alat (tools), dan teknik (technique) dalam aktivitas-aktivitas proyek untuk memenuhi kebutuhan-kebutuhan proyek. Manajemen proyek dilaksanakan melalui aplikasi dan integrasi tahapan proses manajemen proyek yaitu initiating, planning, excuting, monitoring, dan controlling. Dalam pelaksanaannya, setiap proyek selalu dibatasi oleh kendala-kendala ang sifatnya saling mempengaruhi dan biasa disebut sebagai project constraint yaitu lingkup pekerjaan (scope), waktu dan juga biaya. Keseimbangan ketika konstrain tersebut akan menentukan kualitas suatu proyek.

Secara umum proyek terbagi menjadi proyek konstruksi, proyek penelitian dan pengembangan serta proyek yang berhubungan dengan manajemen jasa. 
Proyek konstruksi biasanya berupa pekerjaan membangun atau membuat produk fisik, seperti jalan, bangunan, bendungan, jembatan, pabrik, dan lain sebagainya. Menurut Yasin (2005), proyek konstruksi adalah suatu kegiatan yang hasil akhirnya berupa bangunan/konstruksi yang menyatu dengan lahan kedudukannya, baik digunakan sebagai tempat tinggal atau sarana kegiatan lainnya. Kegiatan konstruksi meliputi perencanaan, persiapan, pembuatan, pembongkaran dan perbaikan bangunan.

Sebagian besar pelaku bisnis proyek konstruksi kurang memiliki latar belakang pengetahuan di bidang manajemen. Padahal pengetahuan di bidang manajemen sangat dibutuhkan untuk meningkatkan performa usaha yang memiliki keunggulan bersaing dan daya tahan dalam menghadapi persaingan yang kian ketat. Oleh karena mutlak dibutuhkan adanya manajemen konstruksi yang baik. Malik (2010) mendefinisikan manajemen konstruksi sebagai proses menggerakkan, memanfaatkan, dan mengkordinasikan segala sumber daya yang dimiliki secara efektif da efisien untuk mencapai tujuan usaha konstruksi.

Istilah kontrak kerja konstruksi merupakan terjemahan dari construction contract. Kontrak jenis ini dikenal dalam pelaksanaan konstruksi bangunan, baik yang dilaksanakan oleh pemerintah maupun swasta. Menurut definisi UU No. 18 tahun 1999 Tentang Jasa Konstruksi mendefinisikan bahwa kontrak kerja konstruksi merupakan keseluruhan dokumen yang mengatur hubungan hukum antara pengguna jasa dan penyedia jasa dalam penyelenggaraan pekerjaan konstruksi (dalam Salim 2003).

Kontrak kerja konstruksi adalah juga kontrak bisnis yang merupakan suatu perjanjian dalam bentuk tertulis dimana substansi yang disetujui oleh para pihak yang terikat di dalamnya terdapat tindakantindakan yang bermuatan bisnis. Sedangkan yang dimaksud bisnis adalah tindakan yang mempunyai aspek komersial. Dengan demikian kontrak kerja konstruksi yang juga merupakan kontrak bisnis adalah perjanjian tertulis antara dua atau lebih pihak yang mempunyai nilai komersial (Juwana, 2001).

Resiko muncul karena adanya kondisi ketidakpastian. Resiko bisa didefinisikan dengan berbagai kejadian yang merugikan akibat adanya ketidakpastian sehingga apa yang diperoleh menyimpang dari yang diharapkan (Hanafi, 2009). Resiko terdiri dari resiko yang bisa diprediksi (predictable risk) dan resiko yang tidak bisa diprediksi (unpredictable risk). Resiko yang bisa diprediksi adalah segala potensi yang bisa diidentifikasi dan dikuantifikasi sebelum dan selama pelaksanaan pekerjaan. Sedangkan unpredictable risk adalah segara potensi kerugian yang terjadi diluar perhitungan seperti bencana alam, huru-hara, dan kejadian-kejadian bersifat luar biasa (Malik, 2009).

Resiko pada proyek kosntruksi adalah suatu kondisi dimana dampak dari tidak terjadinya suatu resiko dapat menyebabkan tidak tercapainya tujuan suatu proyek, seperti waktu penyelesaian, biaya, dan mutu yang disepakati (Apsiddhal, 2008). Identifikasi terhadap bagian-bagian yang kritis dari risiko adalah langkah pertama untuk melaksanakan penilaian risiko agar tercapai sasaran proyek. Sumber-sumber risiko diidentifikasi berdasarkan pertanyaan mengapa dan bagaimana kemungkinan-kemungkinan risiko yang ada sehingga dapat menyebabkan kerugian (Haimes, 1998). Peluang terbesar terjadinya sebuah peristiwa risiko (misal kesalahan estimasi waktu, estimasi biaya, atau teknologi desain) adalah dalam hal konsep, perencanaan, dan tahap mulai (startup) dari proyek.

Dalam buku panduan kontraktor yang ditulis oleh Triwibowo, et.al., (2003) disebutkan beberapa pasal penting di dalam kontrak konstruksi yang berdasarkan pengalaman kerap kali menjadi sumber perselisihan dengan owner, yang terdiri dari (1) Lingkup pekerjaan: berisi tentang uraian pekerjaan yang termasuk di dalam kontrak (2) Jangka waktu pelaksanaan yang menjelaskan tentang, Total durasi pelaksanaan, Pentahapan (milestone), Hak memperoleh perpanjangan waktu dan Ganti 
rugi keterlambatan (3) Harga borongan yang menjelaskan: Nilai yang harus dibayarkan oleh pemilik kontrak (owner), Sifat kontrak (lump sum atau unit price), dan Biaya-biaya yang termasuk dalam harga borongan. (4) Cara pembayaran, berisi ketentuan tentang : Tahapan pembayaran, Cara pengukuran prestasi (termin), Jangka waktu pembayaran, Jumlah pembayaran yang ditahan (retensi), Denda keterlambatan pembayaran Pekerjaan tambah atau kurang yang berisi : Pendefinisian tentang pekerjaan tambah atau kurang, Dasar pelaksanaan tambah/kurang (seperti adanya perjanjian), Dampak pekerjaan tambah/kurang terhadap harga borongan, Dampak pekerjaan tambah/kurang terhadap waktu pelaksanaan, dan Cara pembayaran pekerjaan tambah/kurang (6) Pengakhiran perjanjian berisi ketentuan tentang : Hal-hal yang dapat mengakibatkan pengakhiran perjanjian, Hak untuk mengakhiri perjanjian, dan Konsekuensi dari pengakhiran perjanjian

Dalam konteks proyek konstruksi, biaya adalah kewajiban pelaksana proyek (kontraktor) yang harus dibayarkan kepada pihak-pihak terkait dalam rangka proses pelaksanaan pekerjaan (Asiyanto, 2010). Dalam hal ini tidak berarti bahwa kewajiban tersebut sudah dibayarkan seluruhnya, namun suatu saat sesuai perjanjian harus dibayar. Sumber daya proyek konstruksi terdiri dari material, tenaga kerja, pendanaan, metode pelaksanaan dan peralatan. Waktu dan biaya merupakan dua hal penting dalam pelaksanaan pekerjaan konstruksi selain mutu, karena biaya yang akan dikeluarkan pada saat pelaksanaan sangat erat kaitannya denga waktu pelaksanaan pekerjaan. Shelton (2002) menyatakan bahwa biaya merupakan salah satu aspek penting, bahkan mungkin yang terpenting dalam siklus kegiatan usaha dan industri konstruksi. Kontraktor yang tidak mempunyai pemahaman tentang komponen biaya, termasuk biaya tidak langsung akan meningkatkan resiko dan eksposur mereka terhadap kegagalan yang tidak perlu.

$$
\text { AACE International }
$$

memodelkan biaya sebagai susunan dari biaya langsung (direct cost) dan biaya tidak langsung (indirect cost). Biaya langsung adalah elemen biaya yang memiliki kaitan langsung dengan volume pekerjaan yang tertera dalam item pembayaran atau menjadi komponen permanen hasil akhir proyek. Sedangkan biaya tidak langsung merupakan elemen biaya yang tidak terkait langsung dengan besaran volume komponen fisik hasil akhir proyek, tetapi mempunyai kontribusi terhadap penyelesaian kegiatan atau proyek. Sementara itu Triwibowo, et.,al., (2003) menuliskan dalam bukunya bahwa praktek perhitungan komponen biaya konstruksi terdiri dari : (1) Perhitungan biaya langsung (direct cost) (2) Perhitungan biaya tidak langsung (indirect cost) (3) Biaya resiko dan (4) Biaya overhead.

Biaya merupakan sejumlah uang yang dialokasikan dalam rangka menyelesaikan pekerjaan. Biaya adalah sumber daya yang terbatas sehingga harus direncanakan dan dikendalikan arus kasnya. Buruknya pengendalian biaya menjadi sebab utama kegagalan sebuah proyek konstruksi (Malik, 2010). Praktek di lapangan, pihak yang paling bertanggung jawab dalam pengendalian biaya adalah para key person pelaksana proyek. Para key person tersebut memiliki kewajiban untuk memantau keseimbangan antara perencanaan biaya dengan pengeluaran kongkretnya. Malik (2010) juga menyatakan bahwa dalam aspek biaya atau harga sebuah proyek harus ada sasaran lain yang harus dicapai yaitu menciptakan selisih positif antara penerimaan dengan pengeluaran.

Efektif tidaknya kinerja biaya proyek sangat tergantung dari resiko-resiko yang harus dihadapi. Semakin tinggi resiko, maka semakin kecil kemungkinan terjadi efektivitas biaya. Seluruh jenis resiko hendaknya sudah dipertimbangkan dan dilakukan analisis memadai untuk kemudian dituangkan ke dalam bentuk pasal-pasal di dalam kontrak. Resiko-resiko yang terkandung di dalam kontrak konstruksi bisa mempengaruhi nilai atau harga sebuah proyek konstruksi (Sofyan, 2010). Hal ini menunjukkan bagaimana pentingnya para key person pengendali biaya konstruksi untuk 
memahami tingkat resiko yang terkandung di dalam sebuah kontrak konstruksi. Semakin para key person proyek memahami unsurunsur resiko yang terdapat di dalam kontrak konstruksi, maka besar kemungkinan mereka akan bisa mengantisipasi dan mengurangi munculnya biaya-biaya yang tak terduga yang bisa menurunkan kinerja proyek dari perspektif biaya.

\section{METODE}

Penelitian dilakukan di PT. Pembangunan Perumahan (Persero) Tbk Divisi Operasi I, yang mencakup kepada Cabang I, II dan III. Waktu pelaksanaan penelitian berlangsung dari bulan Januari 2014 hingga Maret 2014. Yang menjadi populasi penelitian adalah karyawan key person di Divisi Operasi I PT Pembangunan Perumahan (Persero) Tbk, yang terdiri dari para karyawan setingkat manajer yang dalam pelaksanaan tugas-tugasnya secara intensif berinteraksi dengan ketentuan kontrak konstruksi dan juga pengendalian biaya sesuai dengan bidang tugasnya masing-masing. Total jumlah key person sesuai dengan kriteria tersebut berjumlah sebanyak 147 orang. Teknik penetapan jumlah sampel dilakukan secara probability sampling, dimana setiap anggota populasi berkesempatan untuk dipilih menjadi anggota sampel (Ferdinand, 2006:192). Dari hasil formulasi Slovin sampel minimum sebanyak 59,5 Agar hasil penelitian dapat diperoleh dengan lebih akurat maka jumlah sampel ditentukan sebanyak 100 responden. Pemilihan sampel dilakukan dengan teknik cluster sampling yaitu dengan membagi jumlah sampel secara proporsional sesuai dengan area kerja masing-masing responden dan keterkaitan tugas sehari hari responden.

Terdapat dua jenis variabel dalam penelitian ini yaitu variabel independen (variabel yang mempengaruhi) yaitu resiko kontrak konstruksi (X) dan variabel dependen (variabel yang dipengaruhi) yaitu Biaya Konstruksi (Y). Variabel X diukur melalui beberapa indikator yang terdiri dari lingkup pekerjaan, jangka waktu pelaksanaan , harga borongan ,cara pembayaran, pekerjaan tambahan dan pengakhiran perjanjian. Variabel Y diukur melalui Perhitungan biaya langsung (direct cost), Perhitungan biaya tidak langsung (indirect cost), Biaya resiko dan Biaya overhead.

Jenis data yang dipergunakan dalam penelitian ini adalah (1) Data primer, yaitu data yang dihimpun langsung dari sumber pertama. Pengumpulan data dilakukan dengan mempergunakan kuesioner yang akan dibuat dengan model tertutup yang telah menyediakan pilihan jawaban kepada para responden (2) Data sekunder yang diperoleh dari data olahan yang telah dipublikasikan, baik yang berasal dari perusahaan, jurnal penelitian terdahulu, dan buku-buku penunjang yang relevan.

Dalam analisis ini, penulis mempergunakan kaidah validitas berdasarkan Rochaety (2007:96), yang menyatakan bahwa hubungan antara suatu pengukuran dengan suatu kriteria digambarkan dengan nilai korelasi yang disebut koefisien korelasi (r). Kriteria suatu alat ukur dapat disebut valid adalah apabila nilai $r_{\text {hitung }}>r_{\text {tabel. }}$ Item pengujian yang baik memiliki tingkat validitas paling rendah 0,30 . Sementara kaidah reliabilitas sebuah intstrumen penelitian menurut Rochaety (2007:99) dikatakan bahwa nilai koefisien reliabilitas dapat diketahui dengan menggunakan model alpha cronbach's. Koefisien yang reliabilitasnya tergolong baik adalah yang berada antara $0,70-1,00$." Jika nilai koefisien berada di bawah 0,70 maka perlu dilakukan beberapa tindakan penyesuaian.

Untuk menentukan apakah data telah berdistribusi normal atau tidak, maka akan dilakukan pengujian 1 sampel K-S (non parametric test), dengan kaidah berikut (Suliyanto, 2011:75) Jika nilai asymp. Sig (2tailed $)<\alpha(0,05)$, maka secara signifikan data tidak berdistribusi normal. Jika nilai asymp. Sig (2-tailed $)>\alpha(0,05)$, maka secara signifikan data berdistribusi normal.

Persamaan regresi yang baik adalah jika tidak memiliki masalah autokorelasi. Jika persamaan regresi memiliki permasalahan autokorelasi, maka persamaan tersebut menjadi tidak baik atau menjadi 
tidak layak untuk diprediksi. Untuk mengetahui apakah terjadi autokorelasi antar variabel, maka akan dilakukan dengan melakukan pengujian Durbin Watson, dengan kaidah yang telah ditetapkan Priyatno (2009:62)

Uji ini diterapkan untuk analisis regresi berganda, yang terdiri dari dua atau lebih variabel bebas, dimana akan diukur tingkat keeratan dan signifikansi asosiasi (hubungan atau pengaruh), melalui perbandingan besaran koefisien korelasi (r). Untuk mengetahui apakah terjadi masalah multikolinieritas antar variabel independen akan dilakukan dengan mengukur nilai VIF (Varian Inflation Factor) dengan kaidah, apabila nilai VIF > 10, maka dapat dipastikan terjadi masalah multikolinieritas antar variabel independen (Yamin \& Kurniawan, 2009:91). Untuk pembuktian hipotesis pada penelitian ini, dilakukan dengan mempergunakan metode uji beda t-test. Metode ini pada prinsipnya $t$-test merupakan suatu teknik statistik yang digunakan secara luas untuk menguji ada tidaknya perbedaan signifikan antara dua kelompok sampel dengan membandingkan hasil masing-masing nilai tengahnya (mean) atau yang lazim disebut dengan compare means.

Dalam penelitian ini, penulis akan mempergunakan jenis sampel independen, yaitu membandingkan rata-rata (mean) dari kedua kelompok yang berbeda (Yamin \& Kurniawan, 2009), yaitu kelompok proyek pemerintah $\left(\mathrm{n}_{1}\right)$ dan kelompok proyek swasta $\left(\mathrm{n}_{2}\right)$. Untuk melakukan uji beda $t$-test, penulis mendasarkan pertimbangan ada tidaknya perbedaan signifikan diantara dua kelompok sampel apabila (1) Jika $t_{\text {hitung }}>t_{\text {tabel }}$ dan probabilitas atau signifikannya (sig 2 tailed) $<$ $\rho$ 0,05, maka $\mathrm{H}_{0}$ ditolak atau terdapat perbedaan signifikan antara kelompok proyek pemerintah dengan proyek swasta. (2) Jika $t_{\text {hitung }}<t_{\text {tabel }}$ dan probabilitas atau signifikannya (sig 2 tailed) $>0,05$, maka $\mathrm{H}_{0}$ diterima atau tidak terdapat perbedaan signifikan antara kelompok proyek pemerintah dengan proyek swasta.

\section{HASIL}

Hasil pengujian validitas memperlihatkan bahwa kecuali pada indikator $\mathrm{X}_{2} .3$ memiliki nilai $r_{\text {hitung }}>r_{\text {tabel }}$ sehingga sebanyak 23 dari 24 indikator yang ada layak (valid) dan bisa dipergunakan sebagai instrumen penelitian. Sedangkan indikator $\mathrm{X}_{2} .3$ harus dihilangkan karena tidak valid sehingga tidak dapat dipergunakan pada proses selanjutnya. Hasil pengujian reliabilitas memperlihatkan bahwa seluruh nilai alpha cronbach's pada semua indikator telah lebih tinggi dari batas minimum 0,7 sebagaimana yang disyaratkan untuk bisa dikatakan reliabel. Dengan demikian maka seluruh indikator bisa digunakan dalam proses pembahasan selanjutnya. Dari hasil uji normalitas menggunakan KolmogorovSmirnov dengan alat bantu SPSS 17 for windows, diperoleh nilai asymp. Sig. (2 tailed) $0,074>0,05$ sehingga disimpulkan bahwa data-data pada penelitian ini memiliki bentuk distribusi normal. Oleh karena itu, seluruh data yang ada dapat dipergunakan pada proses pengujian parametrik selanjutnya.

Dari hasil pengujian multikolinieritas pada variabel independen proyek pemerintah maupun swasta, diperoleh informasi bahwa seluruh variabel independen memiliki nilai VIF < 10, sehingga disimpulkan bahwa masalah multikolinieritas tidak terjadi dan variabel independen dapat dilanjutkan pada proses selanjutnya. Dikatakan ada perbedaan yang signifikan antara tingkat resiko kontrak dan kinerja biaya antara proyek pemerintah dan swasta apabila nilai Sig. (2-tailed) $<\alpha$ 0,05 , dan tidak dikatakan berbeda signifikan jika nilai Sig. (2-tailed $)>\alpha 0,05$.

\section{PEMBAHASAN}

Berdasarkan hasil penelitian dapat dijelaskan beberapa temuan berkaitan dengan masalah yang diteliti antara lain: 
Tabel 1: Hasil Uji Compare Means Pada Aspek-Aspek Resiko Kontrak dan Kinerja Biaya di Proyek Pemerintah dan Swasta

\begin{tabular}{|c|c|c|c|c|c|}
\hline \multirow[b]{2}{*}{ Variabel } & \multicolumn{2}{|c|}{ Nilai Mean } & \multicolumn{2}{|c|}{$\begin{array}{c}\text { Uji } \\
\text { Beda }\end{array}$} & \multirow[b]{2}{*}{ Kesimpulan } \\
\hline & $\begin{array}{c}\text { Proyek } \\
\text { Pemeri } \\
\text { ntah }\end{array}$ & 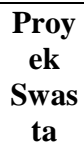 & $\mathbf{A}$ & $\begin{array}{l}\text { fig. (2 } \\
\text { tailed }\end{array}$ & \\
\hline $\begin{array}{l}\text { Lingkup } \\
\text { pekerjaan }\end{array}$ & 4.31 & 4.63 & $\begin{array}{l}0 \\
5\end{array}$ & $\begin{array}{l}0.0 \\
00\end{array}$ & $\begin{array}{l}\text { Tingkat } \\
\text { resiko di } \\
\text { proyek } \\
\text { swasta lebih } \\
\text { tinggi secara } \\
\text { signifikan } \\
\text { dibandingkan } \\
\text { pada proyek } \\
\text { pemerintah }\end{array}$ \\
\hline $\begin{array}{c}\text { Waktu } \\
\text { pelaksanaa } \\
\text { n }\end{array}$ & 3.98 & 3.17 & $\begin{array}{l}0 \\
5\end{array}$ & $\begin{array}{l}0.0 \\
00\end{array}$ & $\begin{array}{l}\text { Tingkat } \\
\text { resiko di } \\
\text { proyek } \\
\text { pemerintah } \\
\text { lebih tinggi } \\
\text { secara } \\
\text { signifikan } \\
\text { dibandingkan } \\
\text { pada proyek } \\
\text { swasta }\end{array}$ \\
\hline $\begin{array}{l}\text { Harga } \\
\text { borongan }\end{array}$ & 4.04 & 3.32 & $\begin{array}{l}0 \\
. \\
0 \\
5\end{array}$ & $\begin{array}{l}0.0 \\
00\end{array}$ & $\begin{array}{l}\text { Tingkat } \\
\text { resiko di } \\
\text { proyek } \\
\text { pemerintah } \\
\text { lebih tinggi } \\
\text { secara } \\
\text { signifikan } \\
\text { dibandingkan } \\
\text { pada proyek } \\
\text { swasta } \\
\end{array}$ \\
\hline $\begin{array}{c}\text { Cara } \\
\text { pembayara } \\
n\end{array}$ & 2.95 & 4.35 & $\begin{array}{l}0 \\
. \\
0 \\
5\end{array}$ & $\begin{array}{l}0.0 \\
00\end{array}$ & $\begin{array}{l}\text { Tingkat } \\
\text { resiko di } \\
\text { proyek } \\
\text { swasta lebih } \\
\text { tinggi secara } \\
\text { signifikan } \\
\text { dibandingkan } \\
\text { pada proyek } \\
\text { pemerintah }\end{array}$ \\
\hline $\begin{array}{l}\text { Pekerjaan } \\
\text { tambah/kur } \\
\text { ang }\end{array}$ & 3.66 & 3.76 & $\begin{array}{l}0 \\
5\end{array}$ & $\begin{array}{c}0.2 \\
11\end{array}$ & $\begin{array}{l}\text { Tingkat } \\
\text { resiko di } \\
\text { proyek } \\
\text { swasta lebih } \\
\text { tinggi namun } \\
\text { tidak } \\
\text { signifikan } \\
\text { dibandingkan } \\
\text { pada proyek } \\
\text { pemerintah }\end{array}$ \\
\hline $\begin{array}{c}\text { Pengakhira } \\
n \\
\text { perjanjian }\end{array}$ & 3.27 & 2.76 & $\begin{array}{l}0 \\
5\end{array}$ & $\begin{array}{l}0.0 \\
00\end{array}$ & $\begin{array}{l}\text { Tingkat } \\
\text { resiko di } \\
\text { proyek } \\
\text { pemerintah } \\
\text { lebih tinggi }\end{array}$ \\
\hline
\end{tabular}

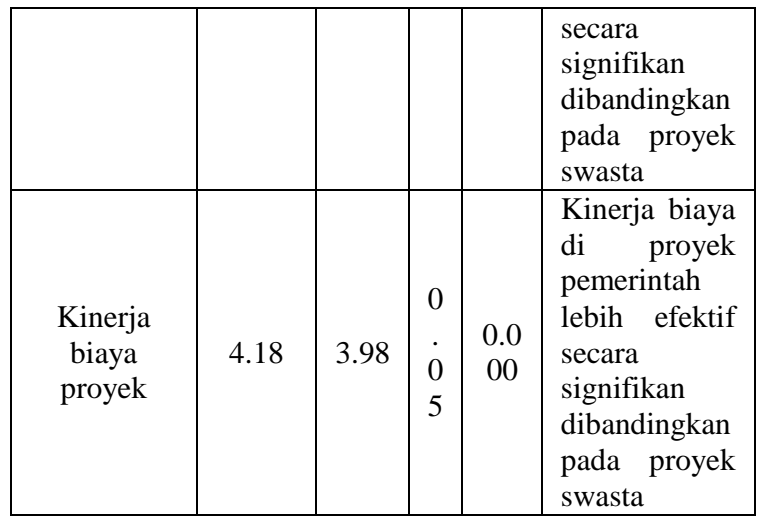

Sumber: Data diolah

Dengan mendasarkan kesimpulan pada Tabel 4.21 tersebut maka dapat dikatakan bahwa terdapat kelebihan dan kekurangan masing-masing pada proyek pemerintah dan swasta. Kelebihan pada proyek pemerintah adalah pada kinerja biayanya yang efektif karena tingkat resiko pada aspek lingkup pekerjaan, cara pembayaran, dan pekerjaan tambah/kurang yang lebih rendah dibandingkan yang terjadi pada proyek swasta. Sementara kinerja biaya pada proyek swasta cenderung kurang efektif akibat resiko pada aspek lingkup pekerjaan, cara pembayaran, dan pekerjaan tambah kurang yang lebih tinggi dibandingkan dengan yang terjadi pada proyek pemerintah. Dari pembahasan uji perbandingan pada keenam aspek tingkat resiko kontrak konstruksi dan efektivitas biaya yang terjadi, maka dapat disimpulkan bahwa:

Tabel 2:

Kesimpulan Pengujian Perbandingan

\begin{tabular}{|c|c|c|c|}
\hline No & $\begin{array}{c}\text { Bunyi } \\
\text { Hipotesis }\end{array}$ & $\begin{array}{c}\text { Hasil } \\
\text { Penelitian }\end{array}$ & $\begin{array}{l}\text { Pembuktian } \\
\text { Hipotesis }\end{array}$ \\
\hline $\mathrm{H}_{1}$ & $\begin{array}{l}\text { Proyek milik } \\
\text { pemerintah } \\
\text { memiliki } \\
\text { efektivitas } \\
\text { biaya yang } \\
\text { lebih baik } \\
\text { secara } \\
\text { signifikan } \\
\text { dibandingkan } \\
\text { proyek milik } \\
\text { swasta }\end{array}$ & $\begin{array}{l}\text { Kinerja biaya } \\
\text { di proyek } \\
\text { pemerintah } \\
\text { lebih efektif } \\
\text { secara } \\
\text { signifikan } \\
\text { dibandingkan } \\
\text { pada proyek } \\
\text { swasta }\end{array}$ & Terbukti \\
\hline $\mathrm{H}_{2}$ & $\begin{array}{l}\text { Proyek } \\
\text { swasta } \\
\text { memiliki } \\
\text { tingkat } \\
\text { resiko }\end{array}$ & $\begin{array}{l}\text { Resiko } \\
\text { kontrak } \\
\text { proyek } \\
\text { swasta lebih } \\
\text { tinggi terjadi }\end{array}$ & $\begin{array}{c}\text { Tidak } \\
\text { sepenuhnya } \\
\text { terbukti }\end{array}$ \\
\hline
\end{tabular}




\begin{tabular}{|c|c|}
\hline $\begin{array}{l}\text { kontrak yang } \\
\text { lebih tinggi } \\
\text { secara } \\
\text { signifikan } \\
\text { dibandingkan } \\
\text { dengan } \\
\text { kontrak } \\
\text { proyek } \\
\text { pemerintah }\end{array}$ & $\begin{array}{l}\text { pada aspek } \\
\text { lingkup } \\
\text { pekerjaan, } \\
\text { cara } \\
\text { pembayaran, } \\
\text { dan } \\
\text { pekerjaan } \\
\text { tambah } \\
\text { kurang. } \\
\text { Sementara } \\
\text { tingkat } \\
\text { resiko di } \\
\text { proyek } \\
\text { pemerintah } \\
\text { terkait aspek } \\
\text { waktu } \\
\text { pelaksanaan, } \\
\text { harga } \\
\text { borongan, } \\
\text { dan } \\
\text { pengakhiran } \\
\text { perjanjian } \\
\text { adalah lebih } \\
\text { tinggi } \\
\text { dibandingkan } \\
\text { tingkat } \\
\text { resiko } \\
\text { kontrak pada } \\
\text { proyek } \\
\text { swasta }\end{array}$ \\
\hline
\end{tabular}

Sumber: Data diolah

Jika dibandingkan dengan penelitian terdahulu seperti Rianto (2009) dan Yansen (2010) Fassa (2011) yang menjadi variabel penelitian adalah lingkup pekerjaan, waktu pelakasanaan, harga borongan, cara pembayaran, pekerjaan tambah/kurang, pengakhiran perjanjian, namun pada penelitian ini seluruh variabel tersebut digunakan sebagai pengukur resiko kontrak pekerjaan konstruksi. Setelah dilakukan pengujian indikator-indikator ini dapat membuktikan bahwa efektifitas biaya proyek milik pemerintah lebih efektif dibandingkan dengan sektor swasta. Selanjutnya pada penelitian sebelumnya efektivitas biaya proyek hanya dijadikan variabel dependen, akan tetapi dalam penelitian ini efektifitas biaya dijadikan sebagai indikator untuk membadingkan efektifitas antara pekerjaan proyek milik pemerintah dan sektor swasta.

\section{SIMPULAN}

Dari hasil pembahasan diatas dapat disimpulkan : Pengelolaan kinerja biaya PT. PP (Persero) Tbk Divisi I pada proyek milik pemerintah sudah efektif, sedangkan kinerja biaya pada proyek milik swasta masih kurang efektif. Dengan demikian maka dapat disimpulkan bahwa pengelolaan efektivitas biaya pada proyek pemerintah lebih baik jika dibandingkan dengan efektivitas biaya pada proyek swasta. Aspek-aspek di dalam kontrak konstruksi PT. PP (Persero) Tbk Divisi Operasi I pada proyek milik pemerintah dan proyek milik swasta samsama memiliki tingkat resiko yang tinggi.

\section{DAFTAR RUJUKAN}

AACE International, 2004. Skills and Knowledge of Cost Engineering, $5^{\text {th }}$ edition. AACE International, West Virginia, USA

Apsiddhal, 2008. Pengalihan Resiko Proyek Konstruksi Pada Perusahaan Asuransi di Indonesia. Rekayasa Sipil, Vol. IV, No. 2, Oktober 2008, hal. 61-71

Asiyanto, 2010. Construction Project Cost Management. Pradnya Paramita, Jakarta

Fassa, Ferdinand, 2011. Identifikasi FaktorFaktor Resiko Terhadap Kinerja Biaya Konstruksi Pada Proyek Pembangunan Perumahan Dilihat Dari Sudut Pandang Kontraktor di Wilayah Jabodetabek. Tesis Universitas Indonesia. http://lontar.ui.ac.id

Ferdinand, Augusty, 2006. Metode Penelitian Manajemen. BPFE Universitas Diponegoro, Semarang

Hanafi, mamduh. M., 2009. Manajemen Resiko. YKPN, Yogyakarta 
Juwana, Hikmahanto, 2001. Dasar-Dasar Kontrak Bisnis. Bahan kuliah Fakultas Hukum, Universitas Indonesia, Jakarta

Malik, Alfian, 2010. Pengantar Bisnis Jasa Pelaksana Konstruksi. CV. Andi Offset, Yogyakarta.

Novrianti, Sari, 2008. Pengaruh Efektivitas Tim Terhadap Kinerja Biaya Proyek Konstruksi. Tesis Universitas Indonesia, Jakarta. http://lontar.ui.ac.id

Priyatno, Duwi, 2009. SPSS Untuk Analisis Korelasi, Regresi dan Multivariat. Gava Media, Yogyakarta

Rianto, Daniel, 2009. Identifikasi FaktorFaktor Yang Mempengaruhi Kinerja Biaya Material Konstruksi Dengan Kontrak Lumpsum. Tesis Universitas Indonesia, Jakarta. http://lontar.ui.ac.id

Rochaety, Ety, 2007. Metode Penelitian Bisnis. Mitra Wacana Media, Jakarta

Salim, H.S., 2003. Perkembangan Hukum Kontrak Innominaat di Indonesia. Sinar Grafika, Jakarta

Santosa, Budi, 2009. Manajemen Proyek: Konsep dan Implementasi. Graha Ilmu, Yogyakarta

Shelton, F., 2002. Indirect Costs of Contracts. Journal of Construction Accounting and Taxation. Vol. 4, p. 3-9.

Sofyan, Mohammad, 2010. Pengaruh Resiko Pada Kontrak Kerja Konstruksi Terhadap Biaya Pekerjaan Konstruksi. Tesis Universitas Indonesia, Jakarta. http://lontar.ui.ac.id
Suliyanto, 2011. Ekonomika Terapan: Teori dan Aplikasi dengan SPSS. Penerbit Andi, Yogyakarta

Triwibowo, et.,al.,. 2003. Buku Referensi Untuk Kontraktor Bangunan Gedung dan Sipil. Gramedia Pustaka Utama, Jakarta

Undang-Undang No. 18 Tahun 1999 Tentang Jasa Konstruksi

Undang-Undang No. 30 Tahun 2000 Tentang Arbitrase dan Alternatif Penyelesaian Sengketa

Yamin, Sofyan, dan H. Kurniawan. 2009. SPSS Complete: Teknik Analisis Statistik Terlengkap Dengan Sofware SPSS. Salemba Infotek, Jakarta

Yansen, Wayan. 2010. Korelasi Antara Pengendalian Kualitas Rencana Pelaksanaan Dengan Kinerja Proyek Konstruksi (Studi Kasus Pada Satuan Kerja Non Vertikal Tertentu Pengembangan Kinerja Pengelolaan Air Minum Provinsi Nusa Tenggara Timur). Jurnal Ilmiah Teknik Sipil, Vol. 14, No. 2, Juli 2010, hal. 188196

Yasin, Nazarkhan, 2005. Mengenal Kontrak Konstruksi di Indonesia. Gramedia Pustaka Utama, Jakarta 